Article

\title{
Impacts of River Engineering on River Channel Behaviour: Implications for Managing Downstream Flood Risk
}

\author{
George Heritage ${ }^{1}$ and Neil Entwistle ${ }^{2, *}$ (i) \\ 1 AquaUoS, University of Salford, Salford M5 4WT, UK; g.l.heritage@salford.ac.uk \\ 2 School of Science, Engineering and Environment, University of Salford, Salford M5 4WT, UK \\ * Correspondence: n.s.entwistle@salford.ac.uk
}

Received: 30 March 2020; Accepted: 5 May 2020; Published: 11 May 2020

check for updates

\begin{abstract}
Although knowledge of sediment transport has improved over the last 25 years, our understanding of bedload transfer and sediment delivery is still based on a limited set of observations or on models that make assumptions on hydraulic and sediment transport processes. This study utilises repeat lidar survey data of the River Caldew above the City of Carlisle in the UK to investigate the balance of erosion and deposition associated with channel switching from an engineered and managed single thread channel to a naturalising incipient wandering system. Over the 11-year survey period (four bankfull flood events) around 271,000 $\mathrm{m}^{3}$ of sediment were delivered to the river and floodplain and $197,000 \mathrm{~m}^{3}$ eroded suggesting that storage rates of around $7000 \mathrm{~m}^{3} /$ annum occurred. The balance of erosion and deposition is influenced by channelisation with very restricted overbank sedimentation and only limited local and transient in-channel bar deposition along the engineered reach $\left(8000 \mathrm{~m}^{3}\right.$ eroded). This contrasts with the activity of the naturalising reach downstream where a developing wandering channel system is acting to store coarse sediment in-stream as large bar complexes and the associated upstream aggrading plane bed reaches and overbank as splay deposits $\left(87,000 \mathrm{~m}^{3}\right.$ stored). Such behavior suggests that naturalisation of channelised systems upstream of flood vulnerable urban areas can have a significant impact on sediment induced flooding downstream. This conclusion must, however, be moderated in the light of the relatively small volumes of material needed to instigate local aggradation in over-capacity urban channels.
\end{abstract}

Keywords: flooding; lidar; wandering; natural sediment management; natural flood management

\section{Introduction}

River channel flood-related maintenance associated with bedload transport deposition is estimated to cost the UK $£ 1.1$ billion annually, and can have a severe impact on infrastructure and local flood risk following extreme events [1,2]; and these costs are expected to increase further under future climate change scenarios [3]. In temperate areas, alluvial river channels are part of a wider functional system that includes, in many instances, an alluvial floodplain. Whilst frequently occurring flows are confined to the active channel, larger less frequent flows exceed the capacity of the channel to contain the discharge, leading to inundation of the floodplain surface, helping to create and maintain the geomorphology and ecology. Whilst flooding is a stochastic process, previous research has demonstrated that floodplain inundation occurs around once every 1.5 to 2 years [4]. Such a frequency of flooding poses problems when floodplain areas are utilised by humans and as such floodplains have been intensively modified from natural to maximise their current economic benefit [5]. 
This manipulation and utilisation of rivers and floodplains has inevitably resulted in degradation of fluvial landforms and processes. The flow and sediment regime has been necessarily modified to accommodate human exploitation. In the context of flood management in the UK, coarse sediment is routinely removed from channel and floodplain areas following flooding to re-establish channel capacity and flood protection levels, to mitigate against local erosion and permit farming. Such a management approach is ubiquitous, with sediment issues treated in isolation from the causative processes [6]. This failure to manage the causes of sediment issues reflects a lack of holistic understanding regarding the coarse sediment transport regime of UK rivers [7].

Stream channelisation is defined as straightening, deepening, and widening of a river, potentially also including bank protection and riparian vegetation management [8] and channelisation programs were designed to prevent lateral erosion of floodplain terrain and to gain arable land. These forms of channelisation have been shown to increase water velocity and flood conveyance locally [9-11]. Channelisation over historic time has resulted in the near complete loss of multi-channel and active meandering systems across Europe [12,13]. River engineering measures directly modify the physical conditions locally and alter upstream and downstream processes promoting adjustments toward a new morphological state [14]. Channel straightening increases stream power, promoting incision and local bed armouring [15,16], and, where armouring is limited, may potentially instigate progressive erosion in the upstream direction [17]. Newly mobilized material generally passes along the channelised reach, accumulating in lower energy reaches downstream and leading to aggradation and river pattern change $[18,19]$. This is well illustrated for the Austrian Danube by [20] where progressive canalisation of the river has occurred in an effort to mitigate downstream sedimentation problems. Importantly too, coarse sediment can accumulate over time along a channelised reach in areas subject to channel widening, such as at structures or where bank protection has failed and the river has eroded the banks. Such zones then suffer an enhanced susceptibility towards overbank flooding.

The brief discussion of potential consequences of channelisation shows that channel adjustments to local alterations most likely affect much longer river reaches. Recent moves to implement catchment based flood management and in particular natural flood management remains based on an incomplete and sometimes questionable knowledge base with a preponderance of modelling studies dominating over a small empirical evidence base. Few, if any, consider the coarse sediment regime and its role in channel dynamics and none have explicitly quantified the impact of naturalisation on sediment flux.

Although knowledge of sediment transport has improved over the last 25 years, our understanding of bedload transfer and sediment delivery is still based on a limited set of observations or on models that make assumptions on hydraulic and sediment transport processes. The Oxford Restatement [3] highlights this through the fact that it discusses land use impact on flooding in terms of run-off production and associated hydrological impact, neglecting the role of sediment. The report acknowledges that the effect of sediment transport on flood hazard is less well understood than that of hydraulics, concluding generally that increasing cross-sectional area will reduce flooding locally, conveying more water downstream where it may increase flood risk for more frequent floods. This has also been demonstrated in several studies spanning the last three decades [21-23].

This study utilises repeat lidar survey data to investigate the balance of erosion and deposition associated with channel switching from an engineered and managed single thread channel to an incipient wandering system and discusses the implications for local and downstream flooding.

\section{Study Site}

The River Caldew was chosen for the study as it is part of the Eden river network which drains a catchment above the City of Carlisle (Figure 1). The city suffered severe flooding in December 2015, associated with the Storm Desmond precipitation event, and triggered a media debate around the requirement to remove sediment from the river system due to its perceived impact on flooding. Currently coarse sediment is periodically removed at Holm Head above the city to counter sediment related urban flooding issues. The catchment is predominantly rural with upland moorland giving 
way to pastoral farming across the valley bottom through to the city of Carlisle. The upper reaches, upstream of the village of Mosedale in the Caldbeck Fells, are relatively steep with extensive areas of exposed bedrock (mudstone and siltstone) and localised coarse sediment input from connected valley-side sources. After Mosedale (the beginning of the overlapping lidar data) through to Linewath Bridge, the river flows over similar bedrock geology, but with thicker and more extensive alluvial drift deposits. The river here is a modified (straightened and embanked) and managed single thread channel constrained within a broad relatively flat valley (inset image Figure 1A). Downstream of Linewath Bridge the channel flows over exposed andesite and basalt, becoming steeper and more confined. Relict fluvio-glacial sediments now armour the bed through this reach. A wide alluvial valley (drift deposits over limestone, sandstone, siltstone and mudstone) occurs between Hesketh Bridge and Buckabank (inset image Figure 1B) followed by another confined reach before the river valley finally opens out around Cummersdale, exhibiting a broad floodplain (alluvial drift deposits over sandstone) through to the outskirts of Carlisle (inset image Figure 1C). It is then engineered through to the confluence with the River Eden in Carlisle (inset image Figure 1D). This pattern is strongly influenced by the underlying geology (mapapps.bgs.ac.uk/geologyofbritain/home.html), where more resistant bedrock has acted as a barrier to the movement of glacial and fluvio-glacial sediments, trapping alluvial material upstream and creating the wide alluvial valley infills which have been later reworked by the river. Evidence of ancient channel activity is preserved in the floodplain and can be seen from aerial photography (inset images Figure 1B,C) with palaeo-channels, bars and splay deposits visible, suggesting active meandering and wandering channels [24] were present prior to historic realignment and subsequent management.

Historic channelisation has impacted all of the alluvial zones along the watercourse in the study area. Planform straightening linked to the construction of the Maryport to Carlisle Railway was performed in early 1840. The Cummersdale area and agricultural floodplain rationalisation further upstream occurred prior to the first epoch ordnance survey map of the area in 1860. This resulted in a shorter, steeper, revetted, partially embanked and tree lined single thread channel. Whilst this channel has remained largely fixed in its planform, it has cut down in the upper alluvial reaches to form over-deep sections with downcutting only moderated by the development of a strong bed armour composed of immobile boulders winnowed from the underlying fluvio-glacial valley floor sediments. Reduced maintenance after Buckabank has seen the river begin to naturalise, recovering to function as an active sinuous single thread channel and as a wandering channel type. Between these alluvial zones the channel is naturally confined through bedrock influenced reaches. Given this pattern of channel types the study reach was divided into 4 sub-reaches; typical morphologic and geometric characteristics are summarised in Table 1. 


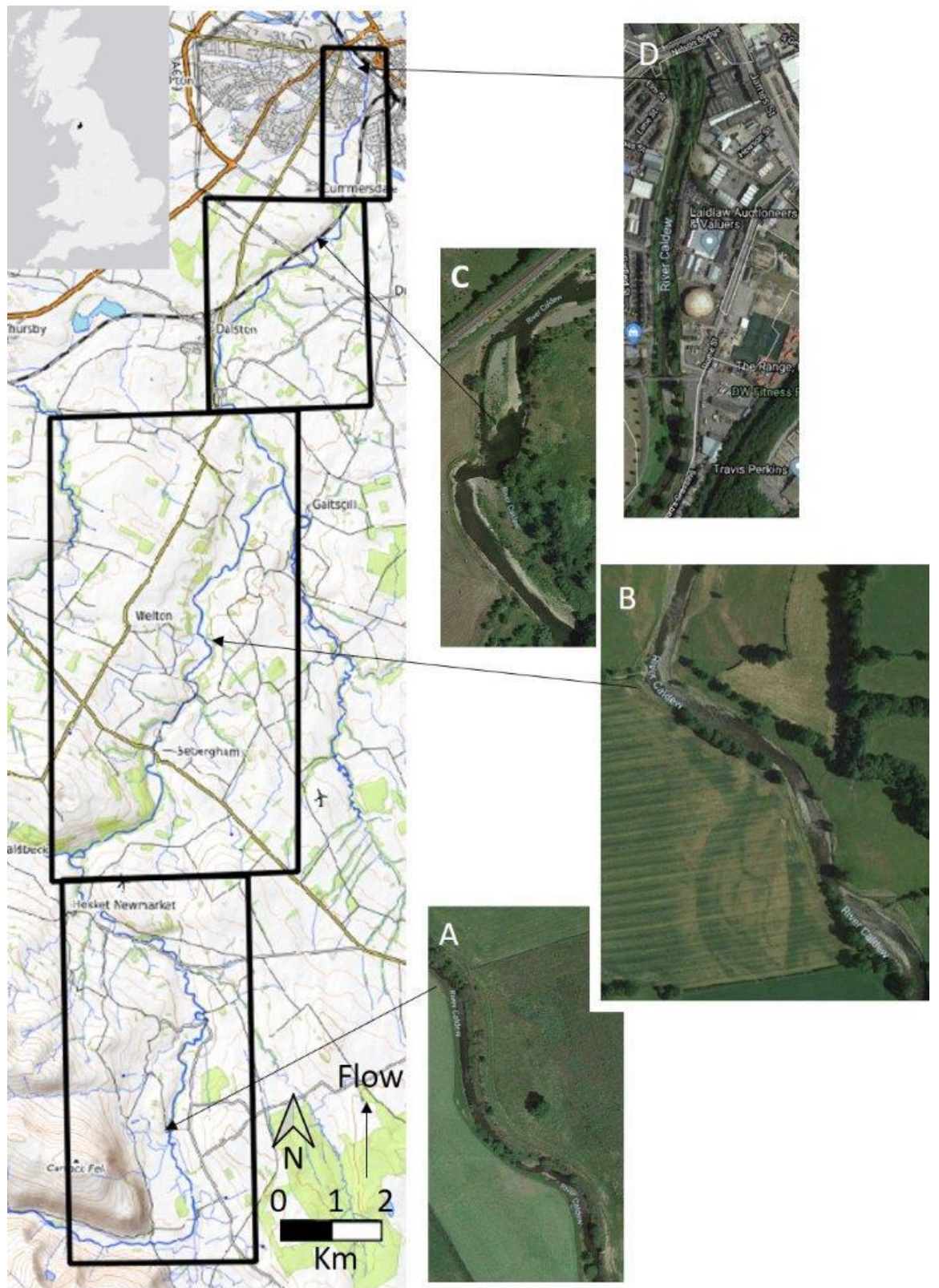

Figure 1. Study reach of River Caldew, Cumbria UK with the reach split into four sections with inset images displaying typical channel types at arrowed locations by Google Earth: Reach 1 Mosedale to Hesketh Bridge ((A) — engineered urban single thread), Reach 2 Hesketh Bridge to Buckabank ((B)-Recovering sinuous single thread), Reach 3 Buckabank to Cummersdale where the river is gauged ((C)—incipient wandering), Reach 4 Cummersdale to Bridge St in Carlisle ((D)-historically channelized restricted sinuous single thread), imagery (C) OpenStreetMap/Maxar Technologies/Google. 
Table 1. Character of the 4 reaches of the River Caldew in the study area.

\begin{tabular}{|c|c|c|c|c|}
\hline Characteristic & $\begin{array}{l}\text { Reach A Mosedale- } \\
\text { Hesketh Bridge }\end{array}$ & $\begin{array}{l}\text { Reach B Hesketh } \\
\text { Bridge-Buckabank }\end{array}$ & $\begin{array}{c}\text { Reach C } \\
\text { Buckabank-Cummersdale }\end{array}$ & $\begin{array}{c}\text { Reach D } \\
\text { Cummersdale-Bridge } \\
\text { St. Carlisle }\end{array}$ \\
\hline $\begin{array}{l}\text { Cumulative catchment } \\
\text { area }\left(\mathrm{km}^{2}\right)\end{array}$ & 83.61 & 220.65 & 249.59 & 259.98 \\
\hline Natural channel type & $\begin{array}{l}\text { Active sinuous single } \\
\text { thread riffle-pool }\end{array}$ & $\begin{array}{l}\text { Active sinuous single } \\
\text { thread riffle-pool Some } \\
\text { confined pool-rapid }\end{array}$ & Wandering & $\begin{array}{l}\text { Active sinuous single } \\
\text { thread riffle-pool }\end{array}$ \\
\hline Impacted channel type & $\begin{array}{l}\text { Artificial fixed planform } \\
\text { sinuous single thread } \\
\text { plane bed }\end{array}$ & $\begin{array}{l}\text { Artificial fixed planform } \\
\text { sinuous single thread, } \\
\text { some pool-rapid }\end{array}$ & $\begin{array}{l}\text { Artificial fixed planform } \\
\text { sinuous single thread plane bed }\end{array}$ & $\begin{array}{l}\text { Artificial fixed planform } \\
\text { single thread plane bed }\end{array}$ \\
\hline Current channel type & $\begin{array}{l}\text { Artificial fixed planform } \\
\text { sinuous single thread } \\
\text { plane bed }\end{array}$ & $\begin{array}{l}\text { Artificial fixed planform, } \\
\text { some laterally active } \\
\text { sinuous single thread, } \\
\text { some pool-rapid }\end{array}$ & Wandering & $\begin{array}{l}\text { Artificial fixed planform } \\
\text { single thread plane bed }\end{array}$ \\
\hline General valley type & Unconfined & Partially confined & Unconfined & Unconfined \\
\hline $\begin{array}{l}\text { Average channel } \\
\text { width }(\mathrm{m})\end{array}$ & 8 & 8 & 10 & 10 \\
\hline $\begin{array}{l}\text { Average channel } \\
\text { depth }(\mathrm{m})\end{array}$ & 1.5-2 (embanked) & $1-1.5$ & $1-1.5$ & 2-3 (engineered) \\
\hline Reach slope & 0.0073 & 0.0068 & 0.0043 & 0.0017 \\
\hline $\begin{array}{c}\text { Reach } \\
\text { Sediment character }\end{array}$ & $\begin{array}{c}\text { Occasional mobile } \\
\text { medium-coarse gravel } \\
\text { over small cobble-coarse } \\
\text { gravel bed }\end{array}$ & $\begin{array}{c}\text { General small } \\
\text { cobble-coarse gravel bed, } \\
\text { Coarse cobble-small } \\
\text { boulder confined reaches }\end{array}$ & $\begin{array}{l}\text { Mixed medium-coarse gravel } \\
\text { and small cobble }\end{array}$ & $\begin{array}{l}\text { Mobile medium-gravel } \\
\text { over small cobble bed }\end{array}$ \\
\hline Floodplain character & Wide, poorly connected & Narrow, occasionally lost & Wide, well connected & Wide, disconnected \\
\hline Channel modification & $\begin{array}{l}\text { Extensively straightened, } \\
\text { deepened, embanked, } \\
\text { revetted, maintained }\end{array}$ & $\begin{array}{c}\text { Some straightening, } \\
\text { deepened, revetted, less } \\
\text { maintained }\end{array}$ & $\begin{array}{c}\text { Historically modified } \\
\text { (as Reach } 1 \text { ), no maintenance, } \\
\text { now naturalising }\end{array}$ & $\begin{array}{c}\text { Extensively straightened, } \\
\text { deepened, widened } \\
\text { embanked, revetted, } \\
\text { maintained }\end{array}$ \\
\hline
\end{tabular}

\section{Data and Methods}

Aerial lidar has been flown across England and Wales capturing river and valley topographic data for several decades (https://environment.data.gov.uk/DefraDataDownload/?Mode=survey). The archive dataset often contains repeat georeferenced survey data; however, these data may become sparse or are less frequent across upper catchment areas. The River Caldew has extensive coverage at $2 \mathrm{~m}$ grid resolution from 2005 and $1 \mathrm{~m}$ resolution for 2016 . A total length of $33 \mathrm{~km}$ of main river were investigated for change between the two surveys using digital elevation models constructed from the lidar data. Precise survey dates were not available, however, the protocol for data collection is for low flow survey maximizing in-channel data capture. Surface comparison and quantification of elevation change was achieved through digital elevation model DEM subtraction using quantum geographic information system (QGIS) software. The change data were examined at the in-channel scale by digitizing the channel centre line and bank edges to delimit this area. Bank erosion and local overbank deposition were quantified by applying a geometry buffer to the channel edge data, isolating the channel margins from the bed and wider overbank floodplain areas (Figure 2A). Overbank erosion and deposition were quantified from the residual volumes calculated during the DEM subtraction process with the bounding area defined by the 1 in 100-year flood outline (Flood Zone 3) published by the English Environment Agency (https://environment.data.gov.uk/DefraDataDownload/ ?mapService $=\mathrm{EA} /$ IndicativeFloodRiskAreas $\&$ Mode $=$ spatial). 

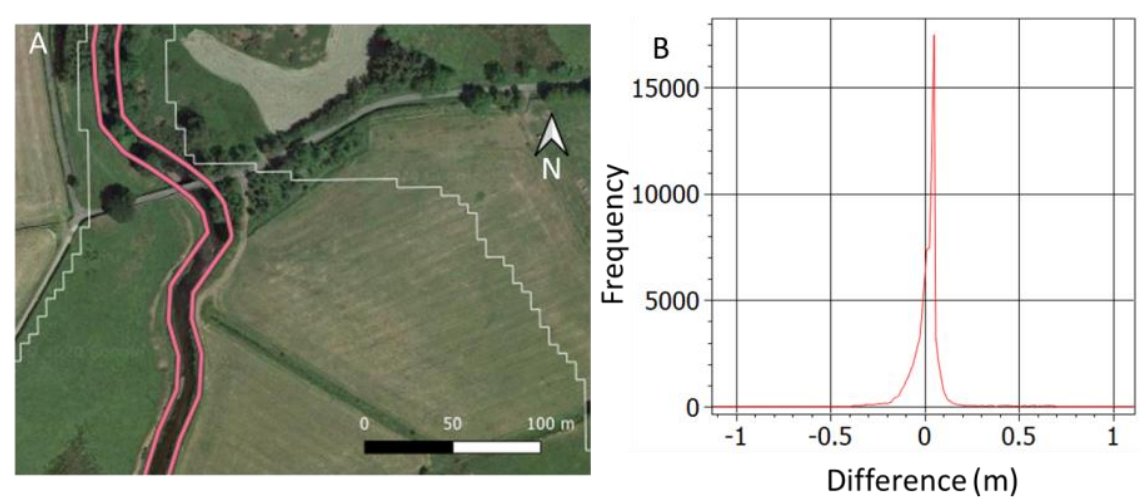

Figure 2. (A) Morphological break points (channel, channel margin—purple, overbank/floodplain—white) and (B) data difference comparison between lidar and laser point cloud used in change analysis (background imagery (C) Maxar Technologies/Google).

\subsection{Error Handling}

When quantifying volumes of erosion and deposition Equation (1) was used to determine the combined error threshold $h_{\text {crit }}$ for each dataset [25]:

$$
h_{\text {crit }}=t \sqrt{\left(\sigma_{E 1}\right)^{2}+\left(\sigma_{E 2}\right)^{2}},
$$

where $\sigma_{E 1}$ and $\sigma_{E 2}$ are the standard deviation of elevation error in the raw survey data, for each

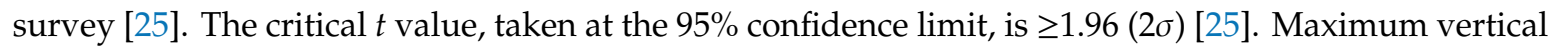
error on the height data is restricted to $\pm 0.15 \mathrm{~m}$ for both surveys (www.arcgis.com/apps/MapJournal/ index.html?appid=c6cef6cc642a48838d38e722ea8ccfee) with most error between $\pm 0.05 \mathrm{~m}$, and this was taken as the value for both $\sigma_{E 1}$ and $\sigma_{E 2}$ as the standard deviation of the error was not available. The gridded lidar was compared with the original airborne laser point cloud for an example grid square. Comparison of aerial lidar ground point position with the interpolated $1 \mathrm{~m}$ Digital Terrain Model (DTM) surface, produced an average mean error of $0.031 \mathrm{~m}$ (close to $0.05 \mathrm{~m}$ error reported above). $95 \%$ of the data are between $-0.24 \mathrm{~m}$ and $0.08 \mathrm{~m}$ (Figure 2B). The resultant threshold applied to the 2005-2016 data comparison was $0.14 \mathrm{~m}$ and this was used to mask the surface difference data. This also eliminates change at the grain scale as it is larger than the c-axis $\mathrm{D}_{84}$ (small cobble, see Table 1) along all reaches.

\subsection{Flow Regime}

Figure 3 plots the flow data at the Cummersdale gauging station located close to the end of the study reach. The estimated bankfull discharge as defined by the Qmed (2-year return period) flow is $159 \mathrm{~m}^{3} \mathrm{~s}^{-1}$ and this is plotted for reference. During the 11-year period between lidar surveys four events were recorded close to or exceeding this value. The period also saw the 2 nd highest recorded flow of $279 \mathrm{~m}^{3} \mathrm{~s}^{-1}$, measured in December 2015, associated with the Storm Desmond precipitation event. 


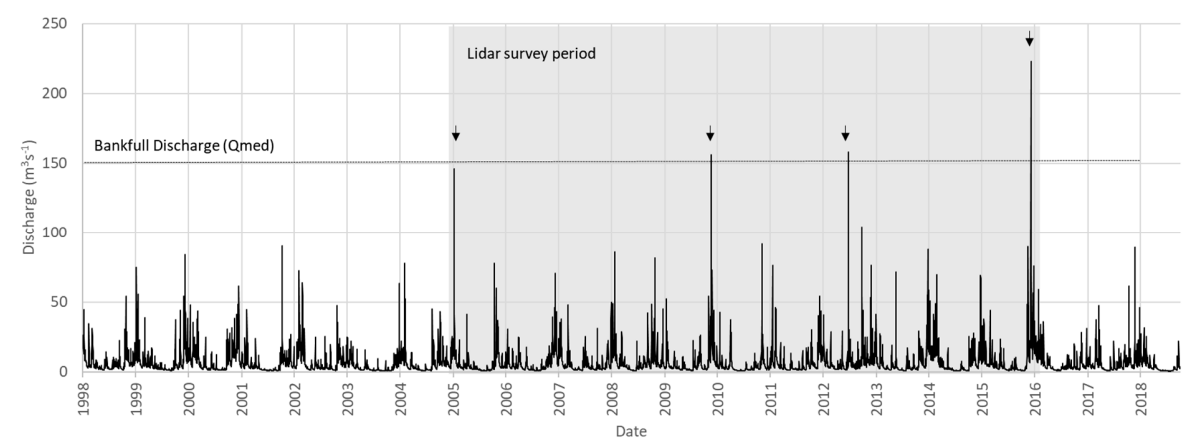

Figure 3. Daily flow data for the River Caldew at Cummersdale, with flows greater than Qmed (the flood with a return period of 2 years) $159 \mathrm{~m}^{3} \mathrm{~s}^{-1}$ indicated.

\section{Results}

The overall pattern of erosion and deposition for the period 2005 to 2016 shows that the channelised Reach A upstream of Hesketh Bridge is remarkably stable with almost no evidence of any activity outside of the active channel (Figure 4A). Reach B is more active; erosion and deposition are more confined to the river edge with localised erosion and associated deposition increasing channel sinuosity (Figure 4B). The incipient wandering Reach $\mathrm{C}$ below Buckabank exhibits general bed raising linked to the development of major bar complexes and overbank splay deposits can be seen extending onto the floodplain. This reach displays the strongest floodplain activity (Figure 4C). Reach D is heavily engineered entering Carlisle and change is restricted to the active channel where deposition dominates (Figure 4D).

Of particular interest are the localised small bar deposits most prevalent in Reach A upstream (Figure 5). These patterns of sedimentation and erosion were observed during the field survey and appear composed of transient sediment that has accumulated on top of a strongly armoured cobble/boulder bed (Figure 6A). This suggests that the channelised upper watercourse appears to be functioning as a transfer reach with bedload delivered from the upper catchment being rapidly moved downstream during floods leaving only limited accumulations of mobile gravels and cobbles as point bars and coarse sediment slugs deposited on the falling limb of a flood across locally depressed energy areas (Figure 6B).

Gross residual erosion and deposition volumes were calculated from the error thresholded change surface (Table 2, Figure 7A). Overall some 271,000 $\mathrm{m}^{3}$ of material was deposited between 2005 and 2016 compared to a loss from the river and floodplain of only $197,000 \mathrm{~m}^{3}$; this suggests that a minimum of $74,000 \mathrm{~m}^{3}$ (or around $7000 \mathrm{~m}^{3} /$ annum) has been delivered and deposited through the study reach from the tributary network outside of the study area. The figures support the general observation of limited change above, and significant deposition below Hesketh Bridge with a net loss of material from Reaches A and B and a larger net gain (around 4 times the upstream loss volume) in Reaches C and D. Areal activity is also significantly contrasting between the modified and managed Reaches A and D and the more naturally functioning Reaches B and C with $19 \%$ of the active area seen in the former two reaches compared to $81 \%$ recorded for Reaches B and C (Table 2). 


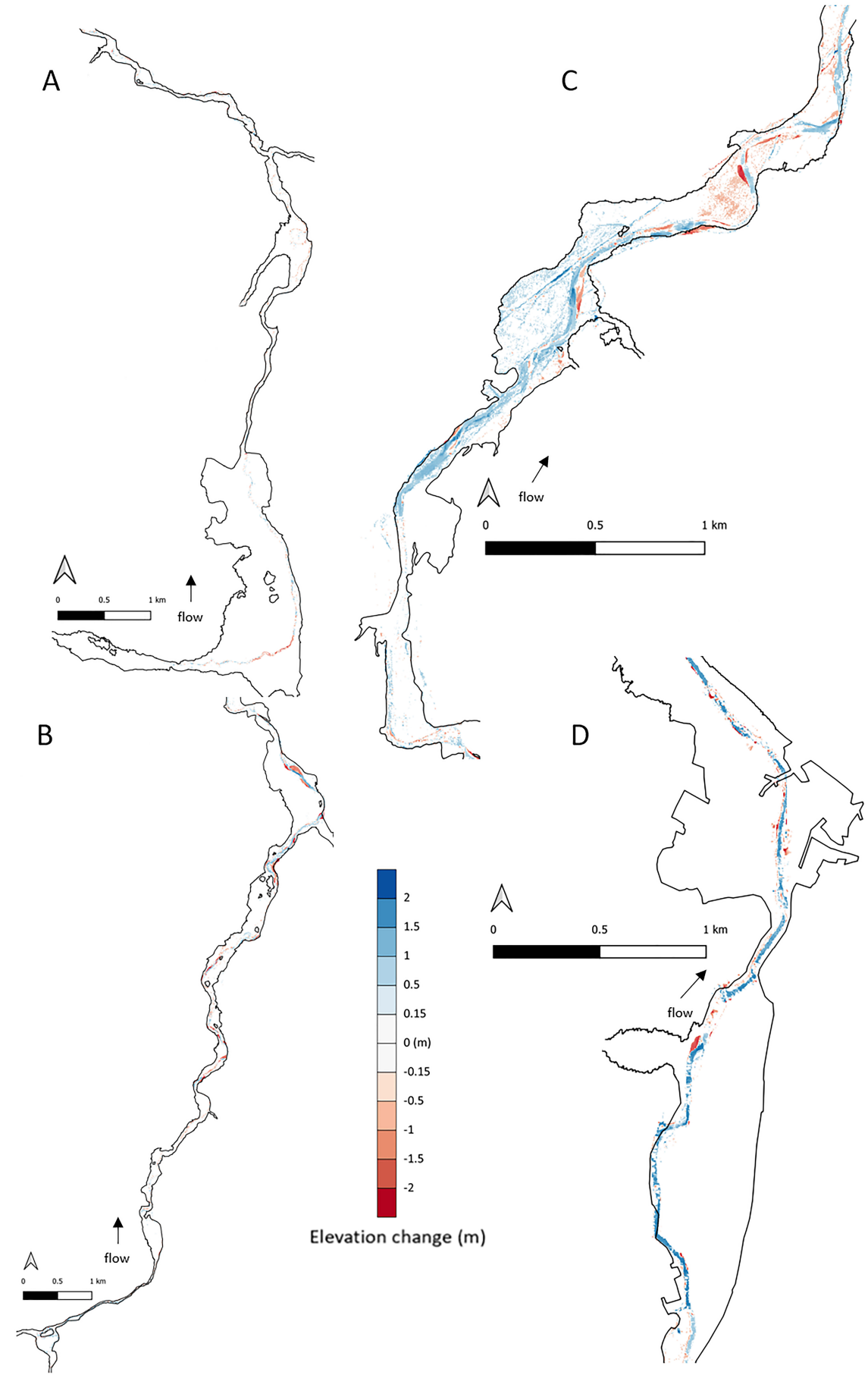

Figure 4. Overall erosion and deposition pattern along the four reaches of the River Caldew study area measured between 2005 and 2016. The black boundary is Environment Agency flood zone 3 representing the 1:100 year return period flow on the annual maximum series. The overall pattern of erosion and deposition for the period 2005 to 2016 shows that the channelised Reach A upstream of Hesketh Bridge is remarkably stable with almost no evidence of any activity outside of the active channel (A). Reach B is more active; erosion and deposition are more confined to the river edge with localised erosion and associated deposition increasing channel sinuosity (B). The incipient wandering Reach C below Buckabank exhibits general bed raising linked to the development of major bar complexes and overbank splay deposits can be seen extending onto the floodplain. This reach displays the strongest floodplain activity (C). Reach D is heavily engineered entering Carlisle and change is restricted to the active channel where deposition dominates (D). 

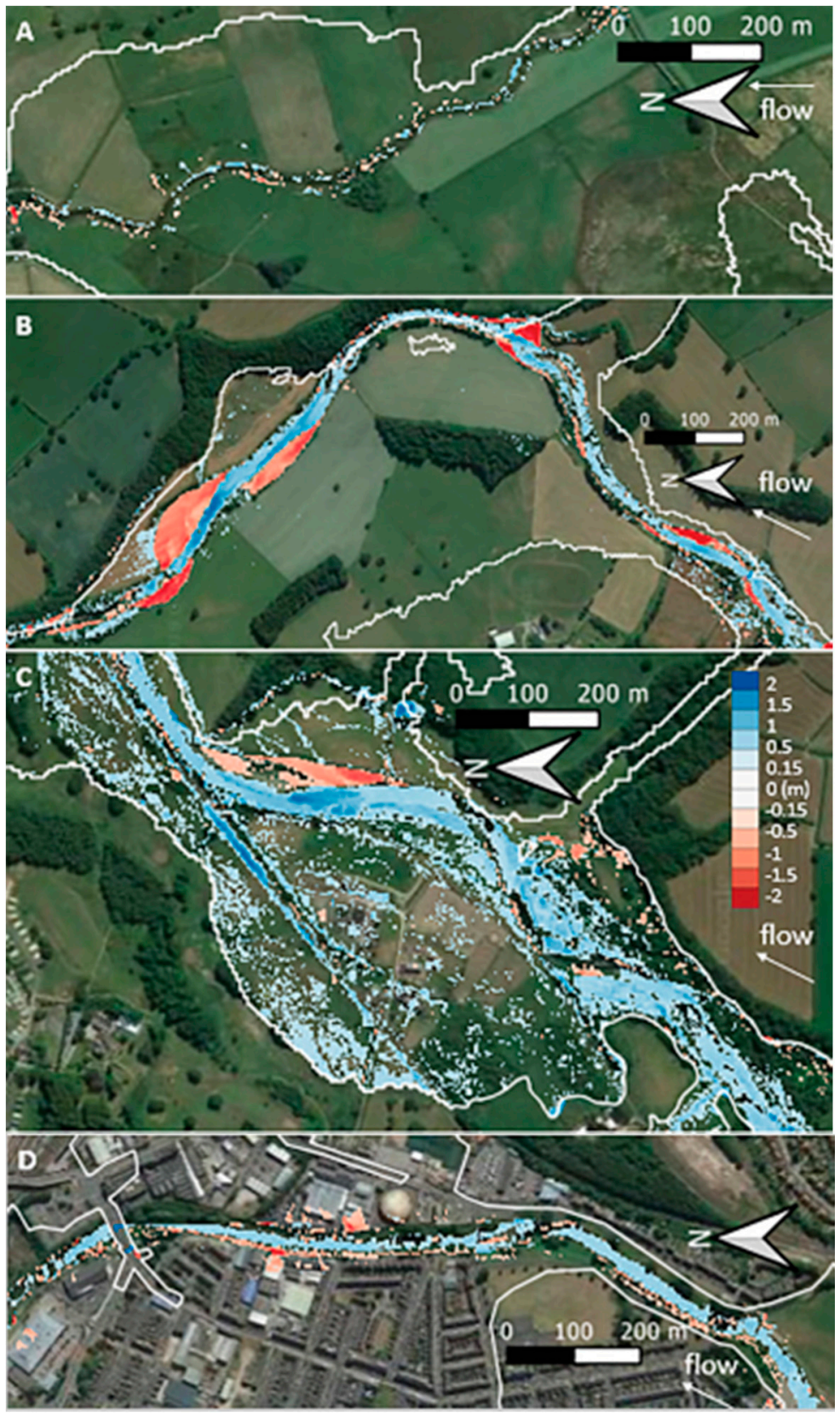

Figure 5. Bank erosion and in-channel sediment accumulation styles within the four reaches of the River Caldew study area measured between 2005 and 2016. The white boundary is the floodplain limit (Environment Agency flood zone 3 representing the 1:100 year return period flow on the annual maximum series) (background imagery (C) Maxar Technologies/Google). Change in the upper Reach A above Hesketh Bridge is associated with transient gravel and cobble deposits moving over a largely fixed armoured channel bed (A) compared to widespread sediment accumulation in Reaches B, C and D below Hesketh Bridge. In Reach B in-channel accumulation occurs as point bar and riffle units (B) and in Reach $C$ as large bar complexes where deposition of mid-channel and lateral bars is associated with channel widening $(\mathbf{C})$, whilst in Reach D accumulation is through more general bed aggradation forming a plane bed channel (D). 

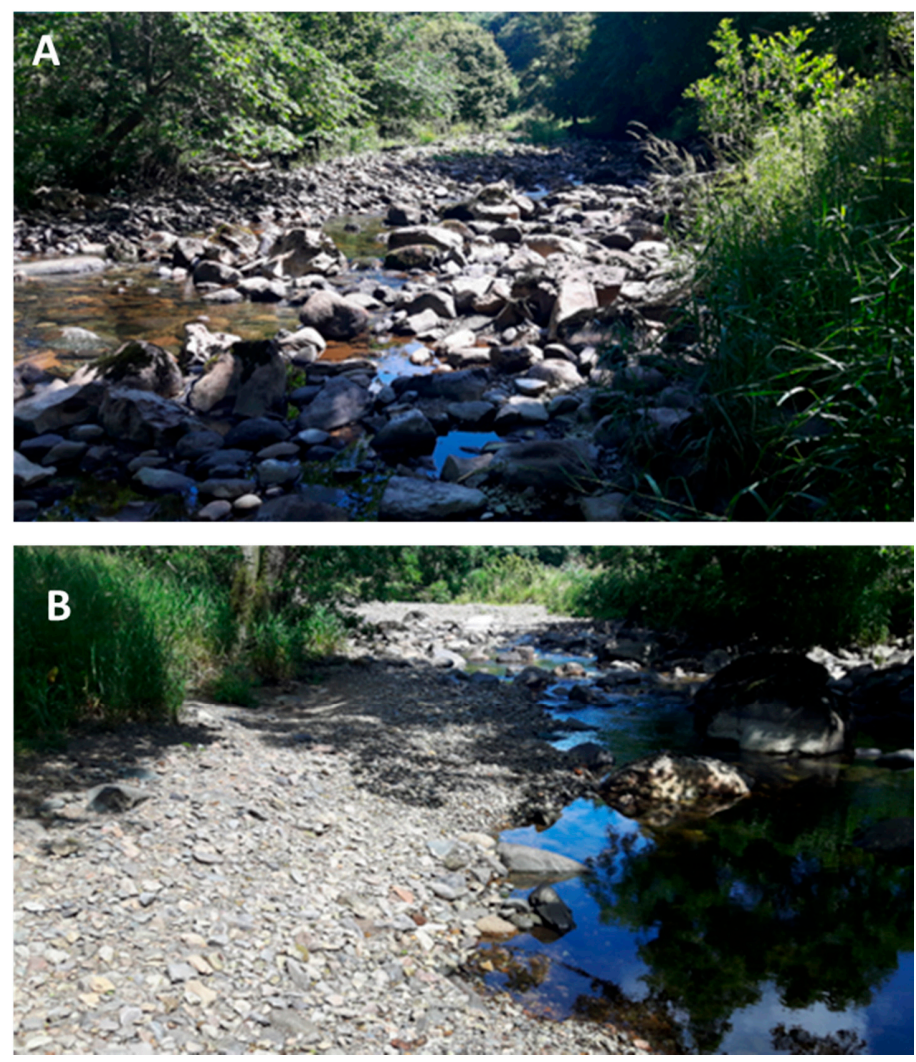

Figure 6. (A) Coarse bed armour rapid feature, and (B) contrasting active bar and slug sediment, along the channelised upper reaches of the River Caldew study area.

Table 2. Summary gross topographic change statistics for the River Caldew between 2005 and 2016.

\begin{tabular}{cccccc}
\hline Change Characteristic & $\begin{array}{c}\text { Reach A Mosedale } \\
\text {-Hesketh Bridge }\end{array}$ & $\begin{array}{c}\text { Reach B Hesketh } \\
\text { Bridge-Buckabank }\end{array}$ & $\begin{array}{c}\text { Reach C } \\
\text { Buckabank-Cummersdale }\end{array}$ & $\begin{array}{c}\text { Reach D } \\
\text { Cummersdale } \\
\text {-Bridge St. Carlisle }\end{array}$ & Combined Reaches \\
\hline Deposition Volume $\left(\mathrm{m}^{3}\right)$ & 19,427 & 91,909 & 130,014 & 30,162 & 271,511 \\
\hline Erosion Volume $\left(\mathrm{m}^{3}\right)$ & 27,449 & 114,455 & 42,937 & 12,789 & 197,629 \\
\hline Net Volume $\left(\mathrm{m}^{3}\right)$ & -8022 & $-22,547$ & 87,077 & 17,373 & 73,881 \\
\hline Deposition Area $\left(\mathrm{m}^{2}\right)$ & 16,929 & 115,720 & 161,690 & 43,759 & 338,098 \\
\hline Erosion Area $\left(\mathrm{m}^{2}\right)$ & 23,911 & 95,462 & 42,108 & 10,953 & 172,433 \\
\hline \% Relative active area & 8 & 41 & 40 & 11 & 100 \\
\hline
\end{tabular}

Gross change across the channel bed (Figure 7B) was quite limited, with minor general in-channel erosion through Reaches A and B and higher gross overall volumes of in-channel deposition through Reaches $C$ and D. Change in the upper Reach A above Hesketh Bridge is associated with transient gravel and cobble deposits moving over a largely fixed armoured channel bed (Figure 5A) compared to widespread sediment accumulation in Reaches B, C and D below Hesketh Bridge. In Reach B in-channel accumulation occurs as point bar and riffle units (Figure 5B) and in Reach C as large bar complexes where deposition of mid-channel and lateral bars is associated with channel widening (Figure 5C), whilst in Reach D accumulation is through more general bed aggradation forming a plane bed channel (Figure 5D). 

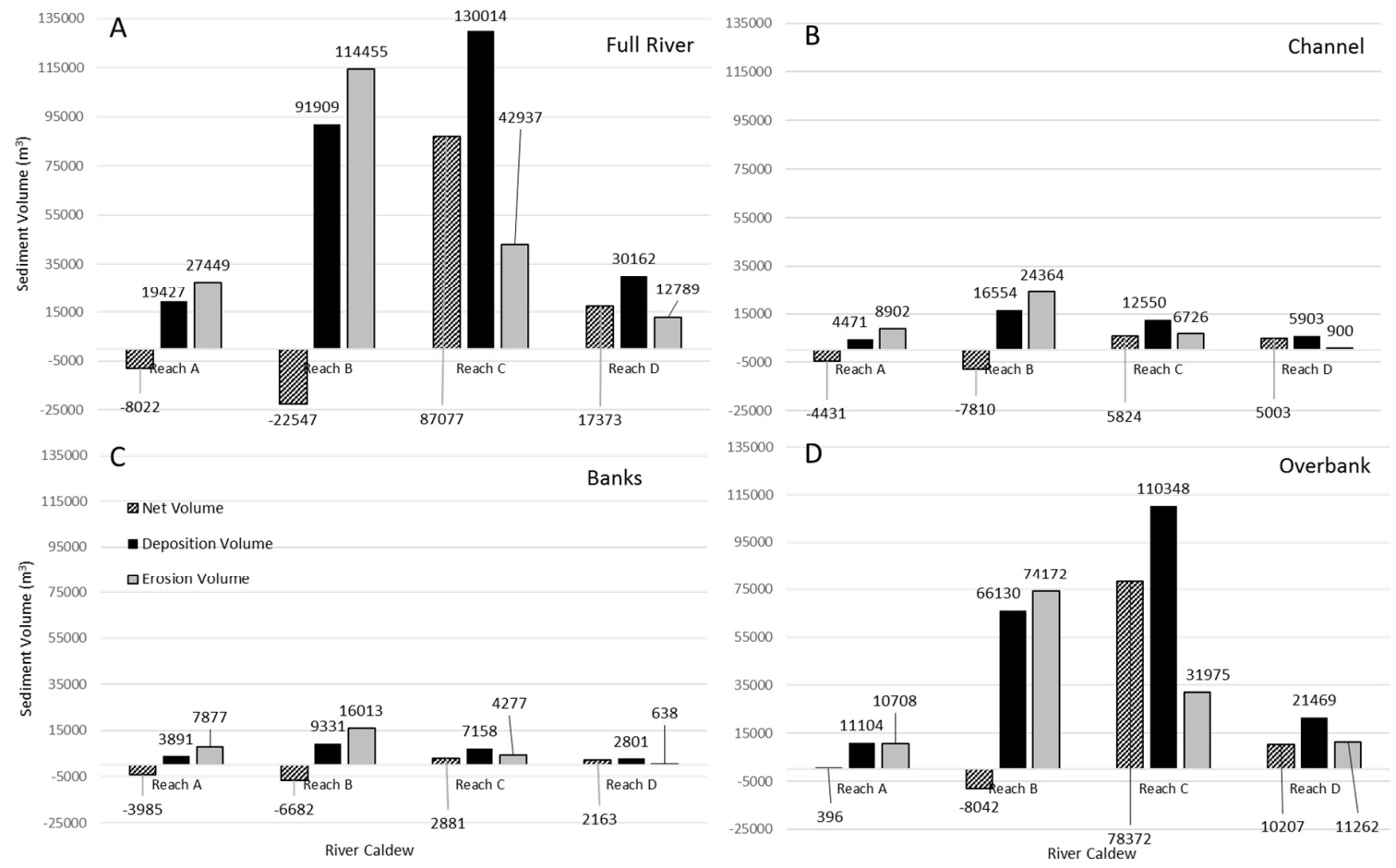

Figure 7. Gross overall in-channel, bank margin and overbank sediment volume change, erosion and deposition, along the River Caldew split by study reaches: (A) all river, (B) in-channel, (C), bank margin and (D) overbank.

Bank change results (Figure 7C) suggest that gross sediment loss from channel banks is small but significant in Reaches A and B but apparently is negated by local overbank deposition along the river in Reaches $C$ and D.

Overbank erosion and deposition results (Figure 7D) show a distinct difference in volumes recorded along Reaches A and B above and below Hesketh Bridge with $8042 \mathrm{~m}^{3}$ of gross sediment loss measured upstream compared to $78,372 \mathrm{~m}^{3}$ of overall sediment deposition in the naturalising wandering Reach $\mathrm{C}$ further downstream. Whilst it is acknowledged that floodplain management of the farmland above Hesketh Bridge will have resulted in underestimation of overbank deposits due to post flood gravel removal, the difference in magnitude still suggests that the channelised Reach A above Hesketh Bridge is acting as a bed sediment transfer reach compared to the storage behaviour of the wandering areas along Reach $C$ downstream.

These gross changes in sediment volume seen between the various channel types masks important and interesting contrasts on erosion and deposition. Reaches A and D overall exhibited the smallest overall volumes of erosion and deposition between 2005 and 2016 (Figure 7A) compared to much higher values through Reaches $B$ and $C$. However, the net deposition in Reach $D$ is significant as this reach runs through a flood vulnerable area. In-channel and bank activity is at a generally low level (Figure 7B,C) compared to overbank erosion and deposition volumes (Figure 7D) with erosion exceeding deposition above and deposition exceeding erosion below Hesketh Bridge. Bank activity is strongest along Reach $\mathrm{B}$ where the channel is becoming more sinuous (Figure $4 \mathrm{~B}$ ) and this contrasts with the wandering Reach $C$ where immediate overbank deposition exceeds lateral erosion. Perhaps the most striking pattern of erosion and deposition is seen across overbank areas (Figure 7D), with activity low through reaches $\mathrm{A}$ and $\mathrm{D}$ where the channel is poorly connected to the floodplain and is largely restricted in its lateral mobility. This contrasts very strongly with Reach B where erosion and deposition almost balance and through Reach $\mathrm{C}$ where considerable storage of sediment has occurred (Figure 7).

The volumes of erosion and deposition in Figure 7 disguise the overall impact as these occur across very different areal extents. Figure 8 elucidates on this, plotting net areal erosion and deposition 
normalised by the area of the bed, banks and floodplain (as defined by the 100-year return period inundation area). It is immediately clear that Reach A has lost relatively modest amounts of sediment both from the bed and banks ( $<0.05 \mathrm{~m}$ areal equivalent), as this has been moderated by bed armouring and revetment respectively. Importantly too, no significant floodplain activity is recorded. The active lateral activity through much of Reach B is reflected in a relatively small net loss of sediment from both the bed and banks associated with a developing sinuous channel and a very minor loss of material from the floodplain (Figure 5B). This contrasts markedly with the behaviour of the wandering Reach $\mathrm{C}$ where large volumes of sediment are being stored across a large floodplain area and local lateral channel erosion is balanced by a significant volume of in-channel sedimentation (Figure 5C). The engineered Reach D through to Bridge Street in Carlisle is interesting from several perspectives; the reach is relatively short but has accumulated a locally significant amount of sediment which has resulted in aggradation of the channel bed and channel margins, with no wider recorded deposition. This suggests that sediment delivery to the reach is over-high, even with the operation of the overbank storage through Reach C, and this is undoubtedly contributing to an increased flood risk locally.

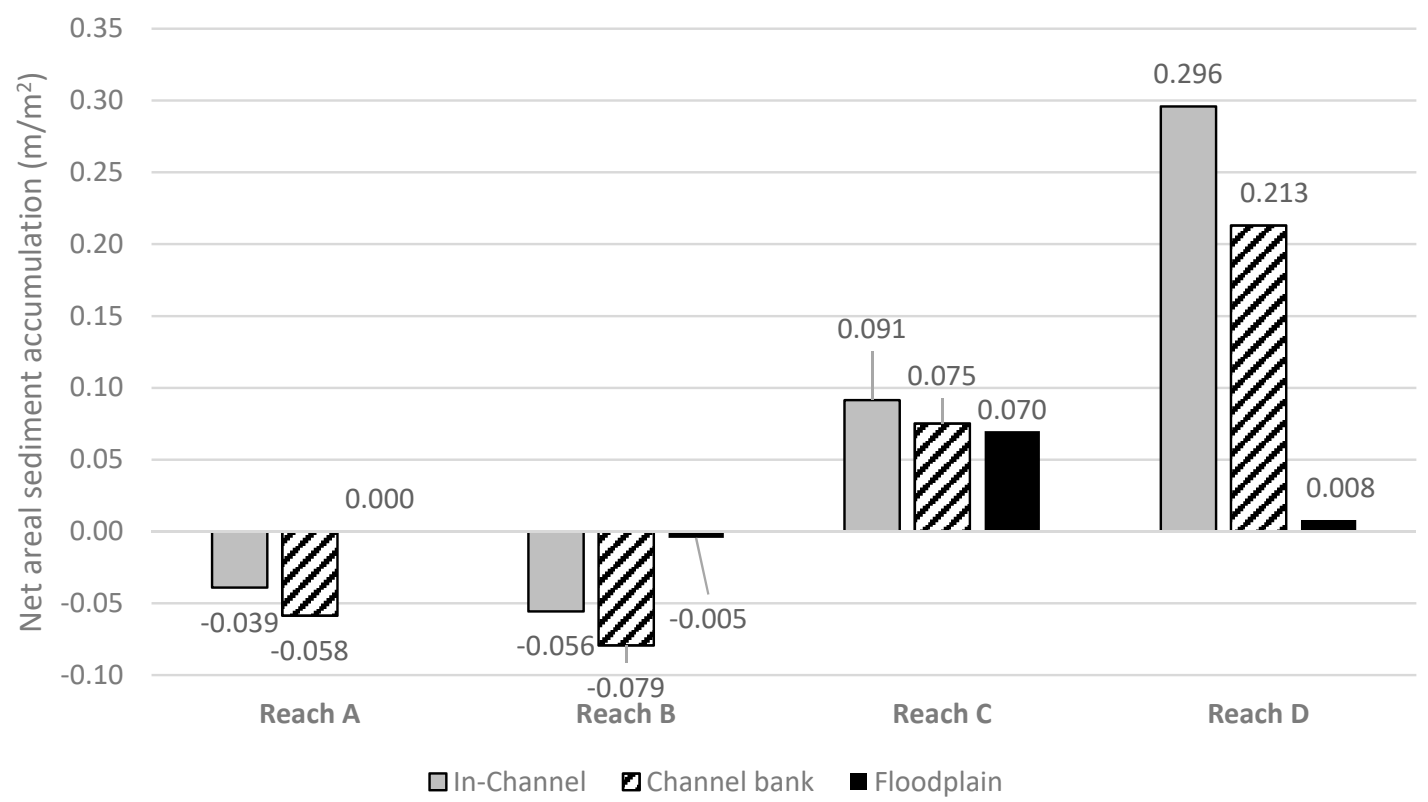

Figure 8. Gross overall in-channel, bank margin and overbank sediment change normalised by area along the River Caldew, split by study reaches.

\section{Discussion}

This paper uses publicly available aerial lidar to investigate erosion and deposition patterns along a geomorphically diverse $33 \mathrm{~km}$ length of river and valley bottom over an extended period of 11 years. This covered four significant geomorphologically effective flood events around or above bankfull. This type of approach has been attempted previously, for example [26] used sequential airborne lidar surveys of a $7 \mathrm{~km}$ long braided river channel in southeastern France to reconstruct a sediment budget. Their results showed that high density (7-9 points $\left./ \mathrm{m}^{2}\right)$ airborne lidar surveys can provide a very high level of detection of elevation difference with a 95\% confidence interval level of detection between 0.19 and $0.30 \mathrm{~m}$. Similarly, [27] studied change along 220 river $\mathrm{km}$ in the Yakima and Trinity River Basins in the USA, concluding that the data were of comparable accuracy to most terrestrial lidar data and river channel bathymetry obtained with photogrammetry. These studies suggest that this approach to the use of large area aerial lidar is capable of detecting erosion and deposition across the fluvial landscape.

The data used has the maximum vertical error on the height data restricted to $\pm 0.15 \mathrm{~m}$ with most error between $\pm 0.05 \mathrm{~m}$; this was verified through review of the laser point cloud ground data with the gridded DEM files. The accuracy reduces over steeper slopes and measured change along the 
bank edge using the lidar surfaces may still contain some error. Such issues were encountered by [25] and [27] who found that apparent bank erosion error increased where slope change occurred at a scale less than the resolution of the data. Field survey suggests that the erosion was not as ubiquitous as the results suggest, especially where riparian tree roots and historic revetment helped resist erosive flow forces. As such the bank erosion values presented above must be treated with a degree of caution where they are limited to the bank margins through channelised reaches. Reliable measurements were seen across areas of coherent local channel migration in Reach B, and where gross channel expansion is associated with the development of the incipient wandering zones (Reach C).

Despite these bank edge issues the results from the repeat lidar change analysis on the River Caldew highlights significant variations in erosion and deposition patterns between Mosedale and Carlisle, suggesting very limited activity in the channelized Reach A above Hesketh Bridge, with coarse sediment presently accumulating predominantly through the naturalising lower reaches. The patterns of change measured in this study suggest that the upper reach channelisation has significantly impacted the coarse bedload sediment regime of the watercourse initially eroding the bed of the channel to form an inset armoured channel which then acts as an efficient conduit for gravel bedload (Reach A). Such a conclusion is supported by research [28] which demonstrated that rivers with restricted lateral activity and floodplain connectivity display increased in-channel responsiveness. Subsequent management has maintained this functionality with Reach A failing to store any delivered bedload either in the channel or across the floodplain zone (Figure 9). Similar findings have been reported illustrating how lateral hydrological connectivity is reduced by the effects of channelisation in the form of bed and consequent water table lowering and embankment construction [29]. Equally important, the exchange of sediment between the river and valley bottom is effectively severed and floodplain processes that help lock up sediment no longer function. This is also demonstrated on the Sussex Ouse floodplain [30] with channelisation effectively fossilizing the river over the last 500 years.

The behaviour of the channelised upper reach on the River Caldew contrasts very strongly with the lower naturalising reaches, which exhibit a sequence of "sedimentation zones" separated by more stable reaches (Figure 9). Similar behavior was reported on the south Tyne [31] and was shown to be present to some degree on 35\% of rivers draining upland England [32]. Such areas have developed because maintenance activity became uneconomic, allowing the main channel to begin to naturalise as a laterally active sinuous single thread channel (Reach B) or a wandering system (Reach C). These areas also illustrate the transient nature of individual bars in the complexes with erosion of bars recorded alongside deposition. It is suggested that this is part of the continuous bar development associated with such widened active channel zones. Such behaviour has also been noted by [33] where a greater width to depth ratio encourages the deposition of alluvial bars and bifurcation of flow following the accretion of sediment as mid-channel bars [34].

From the above, it is argued that many upland floodplain rivers would naturally function as wandering systems, acting in the same way as Reach C on the River Caldew to effectively lock up a large proportion of coarse bedload as in-channel and overbank deposits. In doing so, their development would also dramatically improve channel and floodplain dynamism and diversity recreating floodplain ecosystems managed out of existence [5] by channelisation. This has implications when viewed within the framework of the "jerky conveyor belt" [35] with the wandering stores functioning as a very large scale and long-term disruptors to coarse sediment movement, acting as significant lateral sediment buffers to downstream supply [36]. This natural functioning is also extremely significant with regard to impact on downstream flood risk. The gross transfer of delivered coarse bedload along channelised river lengths results in a strongly elevated supply of sediment downstream. Such sediment may then be stored in low energy reaches where they promote local flooding. This impact has been noted for the River Wharfe [1] where monitored bed elevation change through cross-section resurvey was used in a combined 1D-2D flow model to demonstrate the impact of bed aggradation on flood inundation. The authors concluded that the recorded geometric changes created by increased deposition in the channel led to substantially altered inundated areas for 1-in-0.5-year and 1-in-2-year floods. Their study 
also noted more generally that historic channelisation and agricultural flood management has led to rivers switching from coarse sediment stores to transfer agents. This is a conclusion fully supported and quantified by this study and has significant flood management implications particularly if upland landscapes are more sensitive to climatic fluctuations as a result of historical land-use change [37].

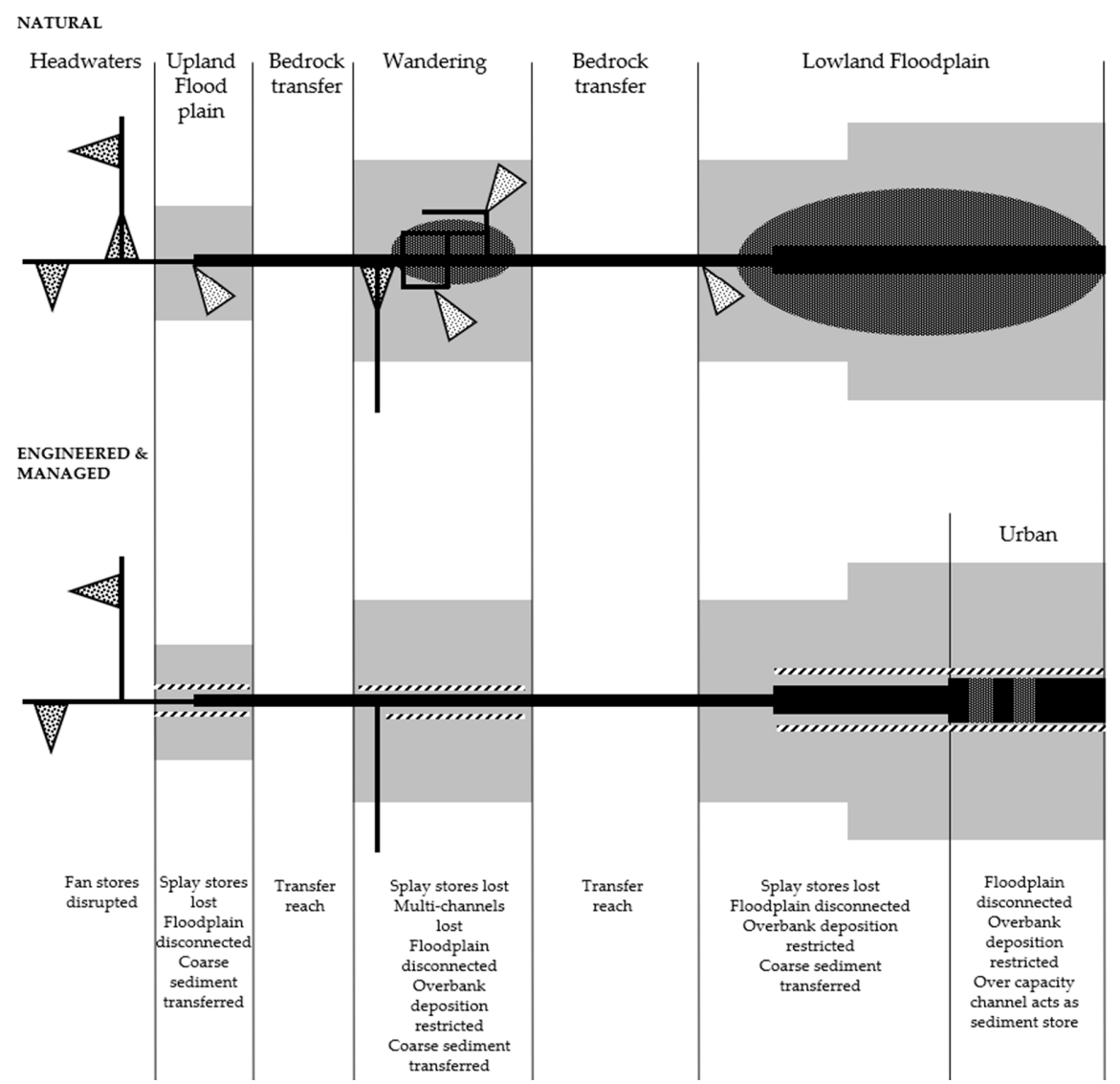

Figure 9. Summary impacts of lost coarse sediment storage due to engineering and management (black—channel, grey—valley bottom, dark grey-fans and splays, and dashed-barriers).

Conclusions drawn from previous catchment research [38] suggest that cultural effects on the hydrology and fluvial response of small catchments is both local and transient with little enhanced cultural imprint on extreme events: This study calls into question this statement, instead concluding that historic river and catchment alteration has in fact grossly impacted on the coarse sediment transport regime enhancing rates of effective transport along channelised reaches and increasing the subsequent risk of channel capacity loss due to aggradation downstream. This is most notable at hotspot depositional sites such as bridges, weirs and bends. It would appear too that this legacy impact may be eased through the reestablishment of naturally functioning river types along the valley bottom with wandering and, to a lesser extent, active meandering reaches acting as buffers to enhanced coarse sediment supply to susceptible areas downstream and this study suggests that such "natural sediment management" approaches should be expanded given the mitigating role they play with regard to aggregational flooding downstream.

On a general level this study supports expert opinion of the recent review of flood processes and management in the UK [3], that coarse sediment transport processes and associated erosion, deposition and morphological dynamism are commonly overlooked in flood risk mapping exercises, but are likely to be important in any river system which receives high rates of sediment delivery and which in the past would have deposited much of its sediment on the floodplain. Coarse sediment storage is ubiquitous in naturally functioning gravel-bed river systems; an extensive alluvial fan on the 
River Wharfe developed after the valley widens at Hubberholme has been shown to act as a general aggregational zone [1] and a similar function associated with the smaller fan that has developed on Liza Beck, near Crummok Water in Cumbria has been reported [39]. This study adds to this evidence base, demonstrating coarse sediment storage through bed aggradation and overbank splay deposition, this time on an unconfined lowland sinuous single thread system. In all three cases natural coarse sediment storage has been effectively neutered through intense historic channel management controlling in-channel and overbank aggradation, switching these systems from coarse sediment storage areas to bedload transfer reaches. Such a transformation has principally been due to historic and current river engineering and management which have ignored sediment transport processes, certainly in a holistic sense. The statement that fluvial geomorphology must be integral to the planning, implementation, and post-project appraisal stages of engineering projects [40] holds true more than ever today.

\section{Conclusions}

A decadal sediment budget has been established for the main river of the Caldew catchment above the city of Carlisle in Cumbria through a comparison of remotely sensed lidar data, revealing volumes and patterns of change along $33 \mathrm{~km}$ of watercourse exhibiting changing channel types. The principal conclusions drawn from the study are summarised in Figure 9 and below:

- Over the 11 year survey period encompassing 4 bankfull flood events around $271,000 \mathrm{~m}^{3}$ of sediment were delivered to the river and floodplain and 197,000 $\mathrm{m}^{3}$ eroded suggesting that storage rates of around $7000 \mathrm{~m}^{3}$ /annum occurred, equivalent to an average areal accumulation of $0.014 \mathrm{~m}$ across the river and entire active river and floodplain area.

- In-channel and channel margin change was small in comparison to overbank change and these data are subject to considerable error along steep margins due to the nature of the lidar data used in the study.

- Channel margin change is severely impacted by channelisation with revetment preventing lateral movement; this results in a natural supply imbalance.

- Change to the main channel bed through erosion is most significant through channelised reaches, but here it appears to be moderated by armouring processes.

- Change to the main channel bed through deposition is most significant through the naturalising wandering reach and the over-deep and over-wide engineered reach downstream where relatively small volumes of sediment have caused aggradation.

- No significant overbank activity was recorded in the channelised reach due to the imposed hydrologic dysconnectivity. All supplied sediment is transferred downstream or stored as transient deposits.

- Encouraging upstream naturalisation towards wandering channel systems can act as a form of "natural sediment management" acting in-combination with other natural flood management approaches to reduce downstream flood risk.

Author Contributions: G.H. and N.E. contributed equally to the creation of this manuscript. All authors have read and agreed to the published version of the manuscript.

Funding: This research received no external funding.

Acknowledgments: The authors would like to thank the Environment Agency for the use of data and Environment Agency geomorphology team for valuable input to the paper. Gratitude in technical support is extended to Robert Williamson and Sebastian Bentley for GIS assistance, and to the four anonymous reviewers for their constructive additions to the manuscript. Partial funding for the research was provided by UKRI.

Conflicts of Interest: The authors declare no conflict of interest. 


\section{References}

1. Lane, S.N.; Tayefi, V.; Reid, S.C.; Yu, D.; Hardy, R.J. Interactions between sediment delivery, channel change, climate change and flood risk in a temperate upland environment. Earth Surf. Proc. Landf. 2007, 32, 429-446. [CrossRef]

2. Slater, L.J. To what extent have changes in channel capacity contributed to flood hazard trends in England and Wales? Earth Surf. Proc. Landf. 2016, 41, 1115-1128. [CrossRef]

3. Dadson, S.J.; Hall, J.W.; Murgatroyd, A.; Acreman, M.; Bates, P.; Beven, K.; O'Connell, E. A restatement of the natural science evidence concerning catchment-based 'natural' flood management in the UK. Proc. R. Soc. A Math. Phys. Eng. Sci. 2017, 473. [CrossRef] [PubMed]

4. Dury, G.H. Bankfull discharge: An example of its statistical relationships. Hydrol. Sci. J. 1961, 6, 48-55. [CrossRef]

5. Entwistle, N.S.; Heritage, G.L.; Schofield, L.A.; Williamson, R.J. Recent changes to floodplain character and functionality in England. Catena 2019, 174, 490-498. [CrossRef]

6. Sear, D.A.; Newson, M.D.; Brookes, A. Sediment-related river maintenance: The role of fluvial geomorphology. Earth Surf. Proc. Landf. 1995, 20, 629-647. [CrossRef]

7. Raven, E.K.; Lane, S.N.; Bracken, L.J. Understanding sediment transfer and morphological change for managing upland gravel-bed rivers. Prog. Phys. Geog. 2010, 34, 23-45. [CrossRef]

8. Hohensinner, S.; Hauer, C.; Muhar, S. River morphology, channelization, and habitat restoration. In Riverine Ecosystem Management; Springer: Cham, Switzerland, 2018; pp. 41-65.

9. Shields, F.D.; Knight, S.S.; Cooper, C.M. Effects of channel incision on base flow stream habitats and fishes. Environ. Manag. 1994, 18, 43-57. [CrossRef]

10. Rheinhardt, R.D.; Rheinhardt, M.C.; Brinson, M.M.; Faser, K.E., Jr. Application of reference data for assessing and restoring headwater ecosystems. Restor. Ecol. 1999, 7, 241-251. [CrossRef]

11. Downs, P.W.; Thorne, C.R. Design principles and suitability testing for rehabilitation in a flood defence channel: The River Idle, Nottinghamshire, UK. Aquat. Conserv. Mar. Freshw. Ecosyst. 1998, 8, 17-38. [CrossRef]

12. Petts, G.E. Historical Analysis of Fluvial Hydrosystems; Wiley: Chichester, UK, 1989.

13. Tockner, K.; Pusch, M.; Borchardt, D.; Lorang, M.S. Multiple stressors in coupled river-floodplain ecosystems. Freshw. Biol. 2010, 55, 135-151. [CrossRef]

14. Brookes, A. Channelized Rivers: Perspectives for Environmental Management; Wiley: Chichester, UK, 1988.

15. Knighton, D. Fluvial Forms and Processes: A New Perspective, 2nd ed.; Routledge: London, UK, 1998.

16. Kesel, R.H. Human modifications to the sediment regime of the Lower Mississippi River flood plain. Geomorphology 2003, 56, 325-334. [CrossRef]

17. Simon, A. The Discharge of Sediment in Channelized Alluvial Streams 1. J. Am. Water Resour. Assoc. 1989, 25, 1177-1188. [CrossRef]

18. Brooks, K.N.; Ffolliott, P.F.; Magner, J.A. Hydrology and the Management of Watersheds; Wiley: Chichester, UK, 2012.

19. Gregory, K.J. The human role in changing river channels. Geomorphology 2006, 79, 172-191. [CrossRef]

20. Schmautz, M.; Aufleger, M. Gravel river widening by bank erosion: Theory and results of physical and numerical modelling. In Proceedings of the River Flow, Louvain-La-Neuve, Belgium, 4-6 September 2002; pp. 639-649.

21. Cooper, J.R.; Gilliam, J.W.; Daniels, R.B.; Robarge, W.P. Riparian Areas as Filters for Agricultural Sediment. Soil Sci. Soc. Am. J. 1987, 51, 416-420. [CrossRef]

22. Howard, A.D. Modeling Channel Migration and Floodplain Sedimentation in Meandering Streams. In Lowland Floodplain Rivers: Geomorphological Perspectives; Carling, P., Petts, G.E., Eds.; John Wiley: Hoboken, NJ, USA, 1992; p. 41.

23. Kajak, Z. The Vistula river and its riparian zones. Hydrobiologia 1993, 251, 149-157. [CrossRef]

24. Desloges, J.R.; Church, M.A. Wandering gravel-bed rivers. Can. Geogr. Géographe Can. 1989, 33, 360-364. [CrossRef]

25. Milan, D.J.; Heritage, G.L.; Large, A.R.; Fuller, I.C. Filtering spatial error from DEMs: Implications for morphological change estimation. Geomorphology 2011, 125, 160-171. [CrossRef] 
26. Tacon, S.; Liébault, F.; Piégay, H. Step by step error assessment in braided river sediment budget using airborne LiDAR data. Geomorphology 2014, 214, 307-323. [CrossRef]

27. Hilldale, R.C.; Raff, D. Assessing the ability of airborne LiDAR to map river bathymetry. Earth Surf. Proc. Landf. 2008, 33, 773-783. [CrossRef]

28. Hooke, J. Coarse sediment connectivity in river channel systems: A conceptual framework and methodology. Geomorphology 2003, 56, 79-94. [CrossRef]

29. Amoros, C.; Bornette, G. Connectivity and biocomplexity in waterbodies of riverine floodplains. Freshw. Biol. 2002, 47, 761-776. [CrossRef]

30. Burrin, P.J. Holocene alluviation in southeast England and some implications for palaeohydrological studies. Earth Surf. Proc. Landf. 1985, 10, 257-271. [CrossRef]

31. Macklin, M.G.; Lewin, J. Sediment transfer and transformation of an alluvial valley floor: The River South Tyne, Northumbria, UK. Earth Surf. Proc. Landf. 1989, 14, 233-246. [CrossRef]

32. Hooke, J.M.; Redmond, C.E. Use of cartographic sources for analysing river channel change with examples from Britain. In Historical Change of Large Alluvial Rivers: Western Europe; John Wiley \& Sons: New York, NY, USA, 1989.

33. Burge, L.M. Stability, morphology and surface grain size patterns of channel bifurcation in gravel-cobble bedded anabranching rivers. Earth Surf. Proc. Landf. 2006, 31, 1211-1226. [CrossRef]

34. Church, M.; Rice, S.P. Form and growth of bars in a wandering gravel-bed river. Earth Surf. Proc. Landf. 2009, 34, 1422-1432. [CrossRef]

35. Ferguson, R.I. Channel forms and channel changes. In British Rivers; Lewin, J., Ed.; Allen and Unwin: London, UK, 1981; pp. 90-125.

36. Fryirs, K.; Brierley, G.J.; Preston, N.J.; Kasai, M. Buffers, barriers and blankets: The (dis)connectivity of catchment-scale sediment cascades. Catena 2007, 70, 49-67. [CrossRef]

37. Macklin, M.G.; Lewin, J. River sediments, great floods and centennial-scale Holocene climate change. J. Quat. Sci. 2003, 18, 101-105. [CrossRef]

38. Newson, M. Land, Water and Development. River Basin Systems and Their Sustainable Management; Routledge: London, UK, 1992; p. 384.

39. Heritage, G.; Entwistle, N. Drone Based Quantification of Channel Response to an Extreme Flood for a Piedmont Stream. Remote Sens. 2019, 11, 2031. [CrossRef]

40. Gilvear, D.J. Fluvial geomorphology and river engineering: Future roles utilizing a fluvial hydrosystems framework. Geomorphology 1999, 31, 229-245. [CrossRef] 